\title{
The Effects of the Covid-19 Pandemic on the Nigeria's Economy and Possible Coping Strategies
}

\author{
Innocent Otache \\ Department of Business Administration and Management, Federal Polytechnic, Idah, Kogi State, Nigeria. \\ Email: otache2@gmail.com
}

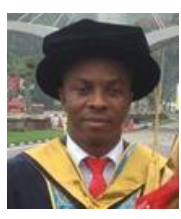

Abstract

The world has been shocked by the outbreak of the Covid-19 pandemic and no country is spared of the effects of the pandemic. However, the effects and strategies to cope with the effects of the pandemic might vary from one country to another. The purpose of this article, therefore, is to identify and discuss the effects of the Covid-19 pandemic on the Nigeria's economy and possible coping strategies. In addition to the viewpoint of the author, this paper undertook a review of the related literature regarding the Covid-19 pandemic and how Nigerians and the Nigerian government can cope with the effects of the pandemic. The review reveals that the effects of the Covid-19 pandemic in Nigeria include jobs losses, a sharp drop in income of the informal workers and the poor, food insecurity, business and school closures, a steep decline in oil revenues and economic uncertainties. This paper has recommended some measures to be adopted by Nigerians and the Nigerian government in order to cope with the devastating effects of the Covid-19 pandemic and similar pandemics in future. The measures include monetary and fiscal policy measures, diversification of the economy through agriculture, revamping of the manufacturing sector, acquisition of relevant ICT skills, adoption of e-learning model by schools, adoption of ebusiness model by business organizations and the need to have multiple sources of income.

Keywords: Coronavirus, Covid-19, pandemic, Economic uncertainties, Nigeria's economy, World Health Organization

JEL Classification: B21, B22, E52, E58, E62, I15.

Citation | Innocent Otache (2020). The Effects of the Covid-19 Pandemic on the Nigeria's Economy and Possible Coping Strategies. Asian Journal of Social Sciences and Management Studies, 7(3): 173179.

History:

Received: 10 June 2020

Revised: 17 June 9090

Accepted: 29 June

Accepted: 22 June 2020

Published: 30 June 2020

Licensed: This work is licensed under a Creative Commons

Attribution 3.0 License $($ (c) $)$ E

Publisher: Asian Online Journal Publishing Group
Funding: This study received no specific financial support.

Competing Interests: The author declares that there are no conflicts of interests regarding the publication of this paper.

Transparency: The author confirms that the manuscript is an honest, accurate, and transparent account of the study was reported; that no vital features of the study have been omitted; and that any discrepancies from the study as planned have been explained.

Ethical: This study follows all ethical practices during writing.

\section{Contents}

1. Introduction

2. What is Covid-19?

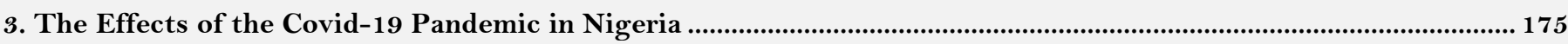

4. Conclusions

5. Recommendations 


\section{Contribution of this paper to the literature}

This paper contributes to the existing literature on how Nigeria and other developing countries can cope with the devastating effects of the Covid-19 pandemic and similar pandemics or crises in future.

\section{Introduction}

The world has been shocked by the outbreak of the Covid-19 pandemic. The World Health Organization (WHO) announced the outbreak of a new coronavirus (SARS-CoV-2) at the beginning of the year 2020 (Adhikari et al., 2020; Congressional Research Service., 2020; Harapan, Itoh, Yufika, Winardi, Keam, Te, et al., 2020). According to WHO, the disease was first reported in the city of Wuhan, China, in December 2019 (Adhikari et al., 2020; Adnan, Khan, Kazmi, Bashir, \& Siddique, 2020; Unhale, Ansar, Sanap, Thakhre, \& Wadatkar, 2020) and has since then spread like a wildfire to more than 190 countries (Congressional Research Service., 2020; Harapan, Itoh, Yufika, Winardi, Keam, Te, et al., 2020). In other words, the disease has become a global pandemic. The pandemic has caused massive economic disruptions across the globe. Economic experts have predicted that the pandemic could plunge the world into a global recession (Ozili, 2020). Also, the pandemic has claimed a significant number of lives across the globe. Table 1 shows the summary of confirmed cases and deaths reported since the outbreak of the Covid-19 pandemic globally as at 24th May, 2020. The table shows that 5,203,796 confirmed cases and 336,559 deaths were recorded globally as at 24, May, 2020.

\begin{tabular}{c|c|c}
\multicolumn{2}{c}{ Table-1. Global Covid-19 statistics as at 24, ${ }^{\text {th }}$ May, 2020.} \\
\hline Region & Total confirmed cases & Total deaths \\
\hline Africa & 77,295 & 2,073 \\
\hline Americas & $2,338,124$ & 138,116 \\
\hline Eastern Mediterranean & 415,806 & 10,988 \\
\hline Europe & $2,006,984$ & 173,886 \\
\hline South-East Asia & 191,966 & 5,748 \\
\hline Western Pacific & 173,621 & 5,748 \\
\hline Total & $5,203,796$ & 336,559 \\
\hline Source: WHO. & &
\end{tabular}

Although the Covid-19 disease broke out in China in December 2019, Nigeria recorded its first index case specifically on the $27^{\text {th }}$ of February, 2020 (Ohia, Bakarey, \& Ahmad, 2020). Since then, the disease has spread to more than 30 states with the confirmed cases and death toll increasing on daily basis according to the Nigeria Centre for Disease Control (NCDC) (Nigeria Centre for Disease Control, 2020). Table 2 shows the number of confirmed cases and deaths reported by the NCDC from $17^{\text {th }}$ to $23^{\text {rd }}$ May, 2020.

\begin{tabular}{c|c|c}
\multicolumn{3}{c}{ Table-2. Nigeria's Covid-19 statistics from $17^{\text {th }}$ to $23^{\text {rd }}$ May, 2020. } \\
\hline Date & Total confirmed cases & Total deaths \\
\hline $17 / 05 / 20$ & 5,621 & 176 \\
\hline $18 / 05 / 20$ & 5,959 & 182 \\
\hline $19 / 05 / 20$ & 6,175 & 191 \\
\hline $20 / 05 / 20$ & 6,401 & 192 \\
\hline $21 / 05 / 20$ & 6,677 & 200 \\
\hline $22 / 05 / 20$ & 7,016 & 211 \\
\hline $23 / 05 / 20$ & 7,261 & 221 \\
\hline Source: $\mathrm{WHO}$.
\end{tabular}

From the statistics presented above, there is no denying that the pandemic has brought untold hardships on Nigerians. Many people have lost their jobs, lives and businesses. The Nigeria's economy has also been badly affected. The pandemic has affected negatively various sectors of the economy such as education, banking, manufacturing, sports, agricultural, aviation, transportation and hospitality, among others. For example, in the aviation sector, the pandemic has led to massive cancellation of flights. The ban on international travels has prevented people from travelling abroad for business and personal purposes. The hospitality industry has also received its own fair share of the effects of the pandemic. Many hotels have been closed down due to the lockdown policy and, definitely, their operations, sales and profits would be affected negatively. Needless to say, many hotel reservations have been cancelled.

Given that the Covid-19 pandemic is relatively recent, articles that discuss its effects on the Nigeria's economy and possible coping strategies are limited. This article, therefore, is among the first to discuss the effects of the Covid-19 pandemic on the Nigeria's economy and possible coping strategies. The article has suggested a number of strategies that can help Nigerians and the Nigerian government cope with the devastating effects of the Covid-19 pandemic and similar pandemics or economic crises in future. Certainly, Nigerians and the Nigerian government will be the first beneficiaries of this article. Also, people from other countries and governments of other countries will find this article useful. Moreover, future researchers will use this article as a reference material.

From the above discussion, the objective of this article is to identify and discuss the effects of the Covid-19 pandemic on the Nigeria's economy and possible coping strategies. To achieve this objective, the remainder of this article is structured as follows: the next section will discuss Covid-19, followed by the section on the effects of the Covid-19 pandemic in Nigeria. Thereafter, the article will be concluded and, lastly, possible strategies on how Nigerians and the Nigerian government can cope with the effects of the Covid-19 pandemic will be identified and discussed.

\section{What is Covid-19?}

Coronavirus disease 2019 is an infectious disease that is popularly known as Covid-19 (Moore, 2020; Ohia et al., 2020). The disease is caused by severe acute respiratory syndrome coronavirus 2; otherwise known as SARS- 
CoV-2 (Adnan et al., 2020; Harapan, Itoh, Yufika, Winardi, Keam, \& Mudatsir, 2020; Ohia et al., 2020; Poudel, Poudel, Gautam, Phuyal, \& Tiwari, 2020). Its symptoms include fever, cough, shortness of breath, sore throat, runny nose, sneezing, among others (Harapan, Itoh, Yufika, Winardi, Keam, \& Mudatsir, 2020; Ohia et al., 2020; Unhale et al., 2020). It is a highly communicable disease (Adnan et al., 2020) and its mode of transmission is from person-to-person (Unhale et al., 2020). Transmission occurs among close contacts mostly through respiratory droplets released when the infected person sneezes or coughs (Harapan, Itoh, Yufika, Winardi, Keam, Te, et al., 2020). While measures such as lockdown, social distancing, self-isolation or self-quarantine and observation of simple hygiene habits such as regular washing of hands, wearing of facemasks and covering the mouth with a handkerchief when coughing or sneezing have been recommended to contain the spread of the disease among people (Ohia et al., 2020) it is important to note that there is no any known cure or vaccine for the Covid-19 pandemic presently (Adnan et al., 2020). Nevertheless, different countries and international organizations like WHO are making efforts to develop vaccines or drugs for the Covid-19 disease.

\section{The Effects of the Covid-19 Pandemic in Nigeria}

Generally, the Covid-19 pandemic has social, religious, political and economic effects on the economy. Some people might argue that it is too early to discuss the effects of the pandemic. However, the pertinent question is, when likely will the pandemic be over? According to experts, the Covid-19 pandemic may not go away anytime soon or completely (Brito, 2020). Besides, there is no cure for it now. Therefore, it is important to discuss the effects now so that measures or actions can be taken to cushion the effects of the pandemic. With that said, the following are the effects of the Covid-19 pandemic in Nigeria.

\subsection{Job Losses}

Many people have lost their jobs as a result of the outbreak of the Covid-19 pandemic and many jobs are in jeopardy in the near future. The pandemic has worsened the unemployment situation in Nigeria. For instance, the unemployment rate in Nigeria before the pandemic stood at 23.1 per cent (CSEA, 2019; National Bureau of Statistics, 2018; NSEG, 2019). However, due to the pandemic, the unemployment rate is estimated to rise to about 33 per cent by the end of 2020 (Obiezu, 2020). An upsurge in unemployment has negative effects on the economy. For example, when unemployment increases there is the likelihood that social vices or criminal activities would increase and this portends grave danger for the country. Also, an upsurge in unemployment could lead to more hunger and poverty in the country.

\subsection{A Sharp Drop in Income of the Informal Workers and the Poor}

The informal workers and the poor are the hardest hit by the Covid-19 pandemic because they live on daily income. This category of people includes street vendors or hawkers, petty traders, taxi drivers, motorcycle (i.e. "Okada") riders, artisans, hairdressers and garbage collectors, etc. They engage in daily trading activities for their daily bread. The lockdown and other containment measures have threatened their means of livelihoods and subjected them further to poverty and hunger. It is important to note that the informal workers constitute about 60 per cent of the global labour force (International Labour Orgnization, 2020) and they live on less than $\$ 2$ per day.

\subsection{Business Closures}

Many businesses, particularly small and medium enterprises (SMEs) have been closed down as a result of the Covid-19 pandemic. SMEs are badly hit by the outbreak of the pandemic due to their vulnerability and limited resources. Measures such as self-isolation or quarantine, social distancing, ban on social gatherings and closure of markets taken to contain the spread of the disease have impacted negatively on their operations, sales and profits. Many SMEs have experienced demand and supply chains shocks during this pandemic. Demands for goods have reduced drastically due to lockdown and restrictions of movement. Additionally, the supply chains have been badly affected. For example, business organizations in Nigeria import their goods from China (Ozili, 2020). With the ban on foreign travels during this pandemic, the supply of such goods and the continuity of such businesses would be negatively affected. Needless to say, border closures have negative impacts on import and export businesses.

\subsection{Agriculture and Food Insecurity}

The Covid-19 pandemic has affected the production and marketing of agricultural products. No doubt, the pandemic has worsened the food insecurity situation in the country. The demand and supply chains of agricultural products and foods internally and externally have been affected as a result of the measures adopted to contain the spread of the disease. Farmers find it difficult to obtain seedlings, fertilizers, pesticides and farm implements. Moreover, labour-intensive agricultural production processes have been affected due to labour shortages and logistical constraints. Additionally, the timing of the outbreak of the Covid-19 pandemic in Nigeria disrupts farming activities. For some farmers, the timing of the outbreak of the disease coincides with the planting season whereas, for others, the timing of the outbreak of the pandemic coincides with the period of harvest. These disruptions, no doubt, have devastating effects on the production and marketing of agricultural products.

\subsection{A Steep Decline in Oil Revenues}

Nigeria is a mono-product economy (Agbaeze \& Ukoha, 2018; National Bureau of Statisticsa, 2019). It depends heavily on the export of crude oil for economic growth and development. The outbreak of the Covid-19 pandemic has affected negatively the price of crude oil in the international market. For example, the price of crude oil dropped from about $\$ 60$ per barrel to less than $\$ 30$ per barrel (Ozili, 2020) and this has affected negatively the revenues from the sales of crude oil for Nigeria. The demand and patronage of Nigeria's crude oil has reduced drastically due to the pandemic. The plunge in the price of crude oil has far-reaching effects on the Nigeria's economy. Specifically, it affects Nigeria's 2020 budget. The steep decline in oil revenues has led to the review of the budget. The Nigeria's 2020 budget was originally N10.594 trillion. It has been reduced to N10.276 trillion. 
Likewise, the oil benchmark that was originally pegged at $\$ 57$ per barrel has been reduced to $\$ 30$ per barrel (Ozili, 2020). It is important to note that revenues from the sales of crude oil form the largest part of the money expected to fund Nigeria's 2020 budget (BudgI, 2020; PWC, 2020).

\subsection{School Closures}

The Covid-19 pandemic has posed a huge challenge to education systems. With the ban on social gatherings and the social distancing measure adopted to contain the spread of the disease, many schools (primary, secondary and tertiary) have been closed down. Academic activities have been suspended and many academic calendars have been disrupted. The implication is that students would not graduate at the expected time.

\subsection{Death Toll}

The coronavirus pandemic has claimed many lives across the country. The statistics released by the NCDC as at $23^{\text {rd }}$ May, 2020 shows that 221 deaths have been recorded since the outbreak of the disease. The number of active cases as at $23^{\text {rd }}$ May, 2020 stands at 5,123 (NCDC, 2020). This is a serious cause for concern considering the poor state of the health facilities in the country.

\subsection{Economic Uncertainties}

The Nigeria's economy is bleak, sliding towards a recession or an economic contraction as a result of the Covid-19 pandemic. Indices of economic recession abound. Prices of goods and services have skyrocketed during this pandemic. Unemployment has increased and exchange rate has become volatile. Moreover, economic activities have been greatly disrupted and the Covid-19 pandemic has no cure for now. This situation makes the economy unpredictable. Additionally, production and job losses and change in buying habits have strained the economy. Moreover, the steep decline in oil revenues occasioned by the sharp fall in crude oil price is likely to deplete Nigeria's external reserves, thereby making the future unpredictable.

\section{Conclusions}

This article identifies and discusses the effects of the Covid-19 pandemic on the Nigeria's economy and possible coping strategies. Generally, the Covid-19 pandemic has social, religious, political and economic effects on the Nigeria's economy. Specifically, the effects of the Covid-19 pandemic in Nigeria include jobs losses, a sharp drop in income of the informal workers and the poor, food insecurity, business and school closures, a steep decline in oil revenues and economic uncertainties.

\section{Recommendations}

The following are the strategies that can help Nigerians and the Nigerian government cope with the devastating effects of the Covid-19 pandemic:

\subsection{Monetary Policy Measures}

Some monetary policy measures have been announced by the Nigerian government through the Central Bank of Nigeria (CBN) with a view to mitigating the effects of the Covid-19 pandemic on the Nigeria's economy. For example, the $\mathrm{CBN}$ has announced a stimulus package of $\mathrm{N} 3.5$ trillion for economic recovery (PKF, 2020). Also, the CBN has approved the sum of N50 billion (\$138.89 million) as a credit facility for households and SMEs that have been badly affected by the pandemic. Another N100 billion ( $\$ 277.78$ million) has been earmarked for the health sector. Additionally, the sum of $\mathrm{N}_{1}$ trillion ( $\$ 2.78$ billion) has been approved as a credit facility for the manufacturing sector. Furthermore, the interest rates on all the CBN interventions have been reduced from 9 to 5 per cent and a one-year moratorium on all the CBN interventions has been introduced.

While the above monetary policy measures have already been taken, there are still more to be done. For instance, the interest rate at which commercial banks lend to SMEs is high and should be reduced. The official interest rate stands at 13.5 per cent (United Capital, 2020). This recommendation is important because not all SMEs are qualified to access the credit facility approved by the CBN for SMEs. Also, the government through the CBN should improve the supply of foreign exchange in order to facilitate import and export trades. All these measures would help to stimulate economic activities in the country and boost the economy.

\subsection{Fiscal Policy Measures}

The Nigerian government should also implement some fiscal policy measures in order to mitigate the effects of the pandemic on the economy. For example, the government should reduce the existing tax rate or give tax breaks to certain SMEs. This would free some money for business expansion. Moreover, the government should increase its spending in the provision of basic infrastructures. For example, the government should invest in electricity. Many SMEs have been generating their own electricity and this has increased the cost of doing business in Nigeria. No doubt, constant supply of electricity would reduce significantly the cost of doing business in Nigeria. Additionally, the Nigerian government should invest heavily in the health sector. The Covid-19 pandemic has exposed the poor state of the health facilities in the country. Investing in the health sector would position the country to cope with similar pandemics in future since Covid-19 might not be the last pandemic. Furthermore, the government should consider the option of direct cash transfers to those who have lost their jobs as a safety net programme in addition to the existing conditional cash transfers to the poor.

\subsection{Diversification of the Economy through Agriculture}

With the steep decline in oil revenues due to the Covid-19 pandemic, it is imperative that Nigeria diversifies its economy. As a matter of fact, diversification of the Nigeria's economy is long overdue. The sudden and steep fall in crude oil price suggests that Nigeria should consider other options of sustaining its economy apart from the oil sector. One of the best options available to Nigeria in its diversification drive is to prioritize agriculture. Nigeria 
needs to focus on agriculture and invest massively in the agricultural sector in order to fully maximize the gains therein. Agriculture has the potential to contribute to the economic development of the country (Praburaj, Design, \& Nadu, 2018; Sertoğlu, Ugural, \& Bekun, 2017; Tahamipour \& Mahmoudi, 2018). Literature review reveals that agriculture provides jobs, income and food (Otache, 2017). Specifically, it provides food for the farmers and ensures food security for the country. Similarly, agricultural produce serves as a source of income to the farmers, as well as a source of revenue to the government. Also, agriculture provides jobs opportunities for the teeming youths. To maximize fully the potentials of the agricultural sector, the government should make agriculture attractive and profitable by formulating agricultural policies that would encourage people to go into agriculture and agribusiness. For example, the government could give financial assistance to the existing and potential farmers in the form of soft loans at a reduced interest rate. Alternatively, the government could buy seedlings, fertilizers, pesticides and farm implements and sell them to farmers at a subsidized rate or distribute those items to farmers free of charge in order to motivate them. Additionally, mechanized and irrigation farming systems should be adopted.

More importantly, the Nigerian youths including young graduates should embrace agriculture and agribusiness. Nigerian youths should take advantage of the availability of vast agricultural land and agribusiness opportunities in Nigeria (Otache, 2017). They could go into farming of crops such as maize and millets or go into poultry and fish farming.

\subsection{Revamping of the Manufacturing Sector}

The manufacturing sector is regarded as the hub of the economy (Uma et al., 2019). However, for many years, the Nigerian government has not accorded the manufacturing sector its rightful place in the development and sustenance of the economy. This is attributable to the oil boom of the 1970s. Thus, Nigeria has become a consuming nation (Bamiro, 2012). Nigeria relies heavily on imports for economic sustenance (Kemi, 2019; Orji, Ogbuabor, Okeke, \& Anthony-Orji, 2018; Uma et al., 2019). Overdependence on imported goods explains why the Nigeria's economy is usually badly affected during global crises. No doubt, the Covid-19 pandemic has taken its toll on the Nigeria's economy. For example, Nigeria imports mainly from China (Ozili, 2020) and with the lockdown and ban on foreign travels during this pandemic, importing goods from China becomes difficult. Moreover, the plunge in oil revenues in the wake of the Covid-19 pandemic has shown that relying on the oil sector alone as the backbone of the economy can be disastrous. Therefore, there is the need to diversify the economy.

In addition to the agricultural sector, the Nigerian government should focus on the manufacturing sector in its economic diversification drive (EDD). Presently, the contribution of the manufacturing sector to the Gross Domestic Product (GDP) is low. For example, available statistics shows that the sector contributed only 9.20 per cent to the GDP in 2018 (National Bureau of Statisticsa, 2019). This statistics suggests that much can be done to improve the performance of the sector. In this regard, the government should invest massively in the sector. Apart from assisting the manufacturers financially, the government needs to invest in infrastructures such as electricity and road construction. Addressing the challenges of electricity and roads in Nigeria would improve significantly the performance of the sector. Also, the government could give tax incentives to manufacturers. It would motivate them and also encourage more people to go into manufacturing. When the sector is revamped, it would not only drive the economic sustainability of the country, but also job opportunities would be created. In the end, the problem of unemployment that is facing Nigeria would be resolved significantly.

\subsection{Adoption of E-Business Model}

With the lessons learnt from the Covid-19 pandemic, business organizations need to come to terms with the new order of doing business, which is e-business. Business organizations must go online if they must remain in business and be competitive. Due to lockdown and restrictions of movement during this pandemic, many customers have adopted online shopping. Interestingly, online shopping allows goods bought to be delivered to the buyer right at the comfort of their home.

Moreover, we are living in a digital world. Thus, business organizations must digitalize their operations. They must adopt emerging automation technologies such as robotics and artificial intelligence in the performance of their activities. Additionally, business organizations must make sure that their employees are equipped with relevant ICT or digital skills to enable them adjust to the new order of doing business.

\subsection{Adoption of E-Learning}

The outbreak of the Covid-19 pandemic has made virtual classrooms or online education system (i.e. elearning) indispensable. Online education system enables students to learn from home. With the lockdown policy and other containment measures enforced during this pandemic, many schools have adopted online education system so that academic activities would not be disrupted. Interestingly, some schools, particularly in developed countries, had adopted online education system even before the outbreak of the Covid-19 pandemic. Nigeria must embrace online education system in addition to the existing traditional classroom system. To do this, the Nigerian government should provide online learning environments and resources. In this regard, the government should make laptops available to students and teachers at a subsidized rate. Also, an affordable internet service should be provided in schools in order to facilitate online teaching and learning. In addition, constant electricity should be provided. More importantly, training programmes should be organized for teachers so that they can acquire digital or e-learning skills for effective online teaching. Likewise, students must acquire basic ICT skills for effective online learning.

\subsection{Acquisition of Relevant ICT Skills}

The shutdown of businesses, government offices and other organizations during this pandemic has made ICT skills indispensable. Remarkably, many employees work from home (i.e. teleworking) during this pandemic. Also, many business and government meetings are held online via video conferencing platforms such as Zoom, Skype and Whatsapp video during this pandemic. Therefore, employees must acquire relevant ICT skills for their services to be retained. Possession of ICT skills is important because telecommuting or teleworking (also known as 
working from home $[\mathrm{WFH}]$ ) may become a new norm even after the pandemic. Also, job-seekers should acquire relevant ICT or digital and e-marketing skills in order to increase their employability. Possession of ICT skills would be an added advantage for job-seekers.

Examples of ICT skills include basic operation of ICT hardware such as printers, scanners, projectors, photocopiers, laptops, smartphones and tablets; Internet usage such as using search engines to search for information; typing, which has to do with the ability to use word processing program to create letters or agenda; email setup and management; social media usage (Twitter, LinkedIn, Instagram, Facebook, etc.); and ability to use communication and collaboration tools such as Slack, Zoom, G-suite, Office 365, WebEx and Skype, etc.

\subsection{The Need for Multiple Sources of Income}

The outbreak of this pandemic has underscored the need for multiple sources of income. Many people have lost their jobs due to the pandemic and some people who depend on one business as a source of livelihood have lost their business. One of the lessons learnt from this pandemic is that relying on one source of income is tantamount to putting all your eggs in one basket and it could be disastrous when that source of income is lost. Having multiple sources of income is important because when one source of income is affected, there would be other source(s) to fall back on. For paid-employees, it is advisable to build other sources of income that can be combined with their main jobs. For example, paid-employees could go into businesses like blogging, rentals, online advertisement or business, investment in stocks with high returns, writing e-books, investment in real estate, website or application design, virtual assistant, small-scale poultry or fish farming, etc.

\section{References}

Adhikari, S. P., Meng, S., Wu, Y.-J., Mao, Y.-P., Ye, R.-X., Wang, Q.-Z., \& Raat, H. (2020). Epidemiology, causes, clinical manifestation and diagnosis, prevention and control of coronavirus disease (COVID-19) during the early outbreak period: A scoping review. Infectious Diseases of Poverty, 9(1), 1-12.Available at: https://doi.org/10.1186/s40249-020-00646-x.

Adnan, M., Khan, S., Kazmi, A., Bashir, N., \& Siddique, R. (2020). COVID-19 infection: Origin, transmission, and characteristics of human coronaviruses. Journal of Advanced Research, 24, 91-98.Available at: https://doi.org/10.1016/j.jare.2020.03.005.

Agbaeze, E., \& Ukoha, K. (2018). Oil a blessing or a curse: The Nigerian experience. European Journal of Social Sciences, 56(3), 262-270.

Bamiro, O. (2012). Determinants of consumption of food away from home in Lagos metropolis, Nigeria. Research Journal of Social Sciences and Management, 2(5), 15-23.

Brito, C. (2020). Coronavirus may never go away. World Health Organization Warns CBC News. Retrieved from https://www.bbc.com/news/world-52643682.

BudgI, T. (2020). 2020 budget analysis and opportunities. Retrieved from https://yourbudgit.com/wp-content/uploads/2020/03/2020Budget-Analysis.pdf. 1-42.

Congressional Research Service. (2020). Global economic effects of COVID-19. Retrieved from https://fas.org/sgp/crs/row/R46270.pdf. 178.

CSEA. (2019). Nigeria economic update. Retrieved from http://cseaafrica.org/nigeria-economic-update-issue-12-4/. 1-3

Harapan, H., Itoh, N., Yufika, A., Winardi, W., Keam, S., Te, H., \& Mudatsir, M. (2020). Coronavirus disease 2019 (COVID-19): A literature review. Journal of Infection and Public Health, 13(5), 667-673.Available at: https://doi.org/10.1016/j.jiph.2020.03.019.

Harapan, H., Itoh, N., Yufika, A., Winardi, W., Keam, S., Te, H., \& Mudatsir, M. (2020). Coronavirus disease 2019 (COVID-19): A literature review. Journal of Infection and Public Health, 13(5), 667-673.Available at: https://doi.org/10.1016/j.jiph.2020.03.019.

International Labour Orgnization. (2020). COVID-19 crisis and the informal economy Immediate responses and policy challenges. Retrieved from https://www.ilo.org/global/topics/employment-promotion/informal-economy/publications/WCMS_743623/lang-en/index.htm. 1-8.

Kemi, A. O. (2019). Nigeria's economy challenges: Causes and way forward. IOSR Journal of Economics and Finance, 1O(2), 78-82.Available at: https://doi.org/10.9790/5933-1002017882.

Moore, N. (2020). Chloroquine for COVID -19 infection. Drug Safety, 43(5), 393-394.Available at: https://doi.org/10.1007/s40264-02000933-4.

National Bureau of Statistics. (2018). Labor force statistics - Unemployment and underemployment Report. Retrieved from https://www.google.com/search?q=Labor+force+statistics+-

+ volume+1\%3A+Unemployment+and+underemployment+Report\&rlz=1C1JZAP_enNG785NG785\&oq=Labor +force+statistics +-+volume+1\%3A+Unemployment+and+underemployment+Report\&aqs=chrome.0.69i59.1474joj8\&sourceid=chrome\&ie=UTF8. $1,1-78$.

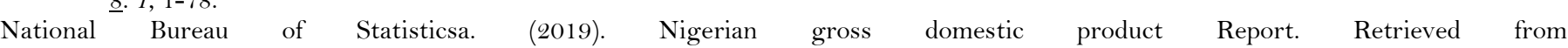
https://www.nigerianstat.gov.ng/pdfuploads/GDP_Report_03_2019.pdf. 1-17.

Nigeria Centre for Disease Control. (2020). Covid-19 situation Report: Situation Report 85, saturday, 23rd may, 2020. Retrieved from https://reliefweb.int/report/world/coronavirus-disease-2019-covid-19-situation-report-85-14-april-2020. 1-4.

NSEG. (2019). Growing an inclusive economy: Job creation and Nigeria's future. Retrieved from https://nesgroup.org/storage/app/public/resource_documents/GIE_growing_inclusive_growth_fullPage-compressed2_1563280585.pdf. 1-30.

Obiezu, T. (2020). Nigeria's jobless pessimistics about finding work as businesses reopen after Covid-19 lockdown, Voice of Africa. Retrieved from https://www.voanews.com/africa/nigerias-jobless-pessimistic-about-finding-work-businesses-reopen-after-covid-lockdown.

Ohia, C., Bakarey, A. S., \& Ahmad, T. (2020). COVID-19 and Nigeria: Putting the realities in context. International Journal of Infectious Diseases, 95, 279-281.Available at: https://doi.org/10.1016/j.ijid.2020.04.062.

Orji, A., Ogbuabor, J. E., Okeke, C., \& Anthony-Orji, O. I. (2018). Another side of the coin: Exchange rate movements and the manufacturing sector in Nigeria. Journal of Infrastructure Development, 10(1-2), 63-79.

Otache, I. (2017). Agripreneurship development: A strategy for revamping Nigeria's economy from recession. African Journal of Economic and Management Studies, 8(4), 474-483.Available at: https://doi.org/10.1108/AJEMS-05-2017-0091.

Ozili, P. K. (2020). Covid-19 pandemic and economic crisis: The Nigerian experience and structural causes. Retrieved from https://ideas.repec.org/p/pra/mprapa/99424.html.

PKF. (2020). Covid-19 PKF Nigeria update. Retrieved from http://pkf-ng.com/media/10046217/pkf-nigeria-covid-19-bulletin-final-ed.pdf. $1-5$.

Poudel, P. B., Poudel, M. R., Gautam, A., Phuyal, S., \& Tiwari, C. K. (2020). COVID-19 and its global impact on food and agriculture. Journal of Biology and Today's World, 9(5), 7-10.

Praburaj, L., Design, F., \& Nadu, T. (2018). Role of agriculture in the economic development of a country. International Journal of Commerce, 6(3), 1-5.Available at: https://doi.org/10.5281/zenodo.1323056.

PWC. (2020). Nigeria economic alert: X-raying the 2020 FGN budget proposal. Retrieved from https://www.pwc.com/ng/en/assets/pdf/economic-alert-nov-2019.pdf. 1-5.

Sertoğlu, K., Ugural, S., \& Bekun, F. V. (2017). The contribution of agricultural sector on economic growth of Nigeria. International Journal of Economics and Financial Issues, 7(1), 547-552.

Tahamipour, M., \& Mahmoudi, M. (2018). The role of agricultural sector productivity in economic growth: The case of Iran's economic development plan. Research in Applied Economics, 1O(1), 16-24.Available at: https://doi.org/10.5296/rae.v10i1.12809. 
Uma, K. E., Obidike, P. C., Chukwu, C. O., Kanu, C., Ogbuagu, R. A., Osunkwo, F. O., \& Ndubuisi, P. (2019). Revamping the Nigerian manufacturing sub-sector as a panacea for economic progress: Lessons from South Korea. Mediterranean Journal of Social Sciences, 1O(4), 111-123.Available at: https://doi.org/10.2478/mjss-2019-0057.

Unhale, S. S., Ansar, Q. B., Sanap, S., Thakhre, S., \& Wadatkar, S. (2020). A review on corona virus COVID-19. World Journal of Pharmaceutical and Life Sciences, 6(4), 109-115.Available at: https://doi.org/10.14744/ejmo.2020.51418.

United Capital. (2020). Nigeria outlook 2020: A different playing field. Retrieved from https://www.unitedcapitalplcgroup.com/wpcontent/uploads/2020/01/Nigeria-Outlook-2020_A-different-playing-field-3.pdf. 1-10. 